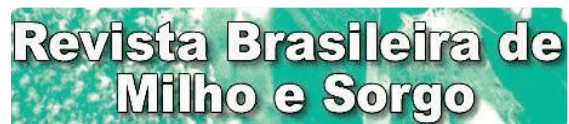

Brazilian Journal of Maize and Sorghum

ISSN 1980 - 6477

Journal homepage: www.abms.org.br/site/paginas

Aline Guimarães Cruvinel $^{(1)}$, Guilherme Braga Pereira $\operatorname{Braz}^{(2)}(\bowtie)$, Gustavo André $\operatorname{Simon}^{(2)}$ Alessandro Guerra da Silva( ${ }^{(2)}$, Leandro Carmo Leão Ribeiro ${ }^{(2)}$ and Túlio Porto Gonçalo(1)

${ }^{(1)}$ Grupo Associado de Pesquisa do Sudoeste Goiano (GAPES)

E-mail: aline.guimaraes@gapescna.agr.br, tulio.goncalo@gapescna.agr.br.

(2)Universidade de Rio Verde

E-mail: guilhermebrag@gmail.com,

simon@unirv.edu.br,

silvaag@yahoo.com.br,

le4ndroribeiro@hotmail.com.

$\checkmark$ Corresponding author

How to cite

CRUVINEL, A. G.; BRAZ, G. B. P.; SIMON, G. A.; SILVA, A. G.; RIBEIRO, L. C. L.; GONÇALO T. P. Interference of increasing densities of sourgrass in grain sorghum. Revista Brasileira de Milho e Sorgo, v. 20, e1213, 2021.

\section{INTERFERENCE OF INCREASING DENSITIES OF SOURGRASS IN GRAIN SORGHUM}

\begin{abstract}
Sourgrass has a high competitive potential, resulting in yield losses of several crops. With the increase of grain sorghum cultivation in the Cerrado, mainly in the second crop, studies are needed to assess the interference of sourgrass on this crop. The objective of this work was to evaluate the interference of increasing densities of sourgrass on the sorghum crop under Cerrado conditions. The field experiment was carried out in a randomized block design, with four replications. Five treatments, composed of densities of $0,2,4,6$, and 8 sourgrass plants per $\mathrm{m}^{-2}$, were evaluated. To simulate the densities of sourgrass, this species was planted in the predecessor crop (soybean) according to the predicted density in each experimental unit, and later, at the time of sowing the sorghum, the sourgrass plants, which were clogged, were cut, in order to simulate the condition provided by mechanized harvesting. During the evaluation of the effect of the treatments on the sorghum crop, the stand and plant height, stalk diameter, panicle length, mass of 100 grains, and yield were measured. The increase in sourgrass density, in coexistence with sorghum, negatively affects all vegetative and reproductive parameters evaluated in the crop. For each sourgrass plant $\mathrm{m}^{-2}$, in coexistence with sorghum, there was a reduction in yield equivalent to $445 \mathrm{~kg} \mathrm{ha}^{-1}$. The maximum reduction in sorghum yield observed was $87 \%$, in a condition in which the crop was developed in coexistence at the density of 8 sourgrass plants $\mathrm{m}^{-2}$.
\end{abstract}

Keywords: Digitaria insularis, weed competition, second crop, Sorghum bicolor.

\section{INTERFERÊNCIA DE DENSIDADES CRESCENTES DE CAPIM-AMARGOSO NO SORGO GRANÍFERO}

\begin{abstract}
Resumo - O capim-amargoso apresenta elevado potencial competitivo, proporcionando perdas no rendimento de diversas culturas. Com o crescimento do cultivo de sorgo no Cerrado, principalmente em segunda safra, se faz necessário estudos que avaliem a interferência do capim-amargoso sobre esta cultura. O objetivo do trabalho foi avaliar a interferência de densidades crescentes de capimamargoso sobre a cultura do sorgo em condições de Cerrado. O experimento foi realizado à campo, no delineamento de blocos casualizados, com quatro repetições. Foram avaliados cinco tratamentos, os quais foram compostos pelas densidades de $0,2,4,6$ e 8 plantas de capim-amargoso por $\mathrm{m}^{-2}$. Para simular as densidades de capim-amargoso, foi realizado o plantio desta espécie na cultura antecessora (soja) de acordo com a densidade prevista em cada unidade experimental, e posteriormente, na ocasião da semeadura do sorgo, procedeu-se o corte das plantas de capim-amargoso, as quais se encontravam entouceiradas, com o intuito de simular a condição proporcionada pela colheita mecanizada. Na avaliação do efeito dos tratamentos sobre a cultura do sorgo, foram mensurados o estande e altura de plantas, diâmetro de colmo, comprimento de panículas e massa de 100 grãos e produtividade. $\mathrm{O}$ aumento da densidade de capim-amargoso em convivência com o sorgo, afeta negativamente todos os parâmetros vegetativos e reprodutivos avaliados na cultura. Para cada planta de capim-amargoso $\mathrm{m}^{-2}$, em convivência com o sorgo, houve redução na produtividade equivalente a $445 \mathrm{~kg} \mathrm{ha}^{-1}$. A máxima redução na produtividade do sorgo observada foi de $87 \%$, na condição em que a cultura se desenvolveu em convivência na densidade de 8 plantas de capimamargoso $\mathrm{m}^{-2}$.
\end{abstract}

Palavras-chave: Digitaria insularis, matocompetição, segunda safra, Sorghum bicolor. 
The production of sorghum in Brazil has grown annually, especially when considering the commercial exploitation of this crop under second crop conditions (known as "safrinha" in Brazil) (CONAB, 2021). This fact can be partially attributed to its greater tolerance to high temperatures and water deficit compared to corn crop. Despite the rusticity of sorghum, in order to obtain higher yields, it is essential to manage agents that have the potential to reduce the yield of this crop, especially weeds (Braz et al., 2019).

In this context, the interference of weeds in sorghum can cause great damage to the development of the crop, creating the need to manage the weed community, from sowing to harvest. In addition, to competing for resources necessary for plant development (water, light, nutrients, and space), weeds can release allelopathic substances, cause difficulties in harvesting, and act as intermediate hosts for various pests, diseases, and nematodes (Braz et al., 2016). Furthermore, the presence of weeds in the reproductive phase, creates an environment with high humidity, favoring the emergence of pathogens in reproductive structures, which culminates in the depreciation of the final quality of the grains produced, this fact, directaly reflects in the loss of yield and lower acceptance of the product by the market.

The susceptibility of sorghum to interference imposed by weeds, is mainly related, to the fact that the crop has a slow initial development, in the first two weeks after emergence (Cabral et al., 2013). Studies show that grain sorghum, in coexistence with weeds, can show a grain yield decrease ranging from $20 \%$ to $97 \%$ (Rizzardi et al., 2004; Rodrigues et al., 2010). Among the weeds that present themselves as the most restrictive for control in sorghum, monocotyledons stand out (Machado et al., 2011), since the effectiveness of herbicides becomes limited due to the morphological similarity between the weed species and the crop. In recent years, due to the intense use of glyphosate in agriculture, and the consequent high selection pressure, reports of glyphosateresistant weeds have been increasing worldwide (Heap, 2021). Among these reports, the existence of sourgrass (Digitaria insularis) biotypes resistant to glyphosate and ACCase inhibitors stands out in Brazil. This weed belongs to the Poaceae family and is characterized by having a perennial cycle, with the formation of clumps and rhizomes, and high seed production capacity, which are easily dispersed (Gemelli et al., 2012). Sourgrass is widespread in practically all of the Brazilian territory (Ovejero et al., 2017), infesting cultivations of the most varied crops, including grain sorghum exploited under second crop conditions.

Due to the inherent difficulties, in the chemical control of sourgrass, and taking into account the scarcity of herbicides registered for sorghum (Pimentel et al., 2019), it is necessary to carry out studies, to quantify the interference potential of this plant weed in the crop. Quantifying the level of interference that sourgrass, has on sorghum can help raise 
awareness among producers on the importance of properly managing this weed.

In this context, the objective of the present work was to evaluate the effect of the interference of increasing densities of sourgrass, on sorghum (BRS $310^{\mathrm{TM}}$ hybrid), cultivated in the Brazilian Cerrado.

\section{Materials and Methods}

The study was carried out in the municipality of Rio Verde, Goiás State, in an experimental farm belonging to Universidade de Rio Verde (UniRV), in the following geographic coordinates: latitude $17^{\circ} 78^{\prime} 60.30$ 'S, longitude $50^{\circ} 96^{\prime} 22.10^{\prime \prime} \mathrm{O}$ and altitude of $770 \mathrm{~m}$. The experiment was installed on March 1st and the harvest was done on June 24th, 2019.

According to Köppen's classification, the climate for the location where the experiment was conducted is of the Aw type, which is called tropical climate with a dry season, characterized by more intense rainfall in summer compared to winter. For this location, the annual average precipitation and air temperature are $1,663 \mathrm{~mm}$ and $23.3^{\circ} \mathrm{C}$, respectively (Climate-Data, 2021). The precipitation and average temperature values observed during the experiment are shown in Figure 1.

Prior to the installation of the experiment, the area had been cultivated with soybeans under harvest conditions (2018/2019). The soil in the experimental area was classified as Dystroferric Red Latosol (Santos et al., 2018), presenting the following physicochemical properties: $\mathrm{pH}$ in $\mathrm{CaCl}_{2}=5.3$; O.M. $=37.6 \mathrm{~g} \mathrm{dm}^{-3} ; 39.5 \%$ sand; $12.0 \%$ silt, and $48.5 \%$ clay under analysis carried out in a layer from 0 to $20 \mathrm{~cm}$ in depth.

The experimental design was a randomized block design, with five treatments and four replications. The treatments were composed of increasing densities of sourgrass infestation in sorghum as follows: 2, 4, 6, and 8 plants $\mathrm{m}^{-2}$, plus a control with the crop not coexisting with sourgrass. Each experimental unit had 5 rows with a length of $5 \mathrm{~m}$, spaced $0.5 \mathrm{~m}$ apart (12.5 $\mathrm{m}^{2}$ ). The central part of each experimental unit was considered as a useful area, excluding $0.5 \mathrm{~m}$ from each end, totaling $6 \mathrm{~m}^{2}$.

To simulate the densities of sourgrass infestation, seedlings of this species were transplanted into the soybean crop according to the predicted density in each experimental unit, following the methodology used by Braz et al. (2021). Soybean plants were harvested manually, and later, at the time of sorghum sowing, the sourgrass plants, which were in bunches, were high cut to simulate the effect of the soybean harvester $( \pm 10 \mathrm{~cm})$. This operation was carried out with a mower coupled to the tractor.

The sowing of sorghum was done mechanically $(03 / 01 / 2019)$ in order to distribute 10 seeds per $\mathrm{m}^{-1}$, with a spacing of 0.5 meters between rows, of the simple hybrid BRS $310^{\mathrm{TM}}$, with Embrapa as the holder. This hybrid presents characteristics of small size, absence of tannin, with red grains, an average height of $1.15 \mathrm{~m}$, and a 120-day cycle, having resistance to lodging 


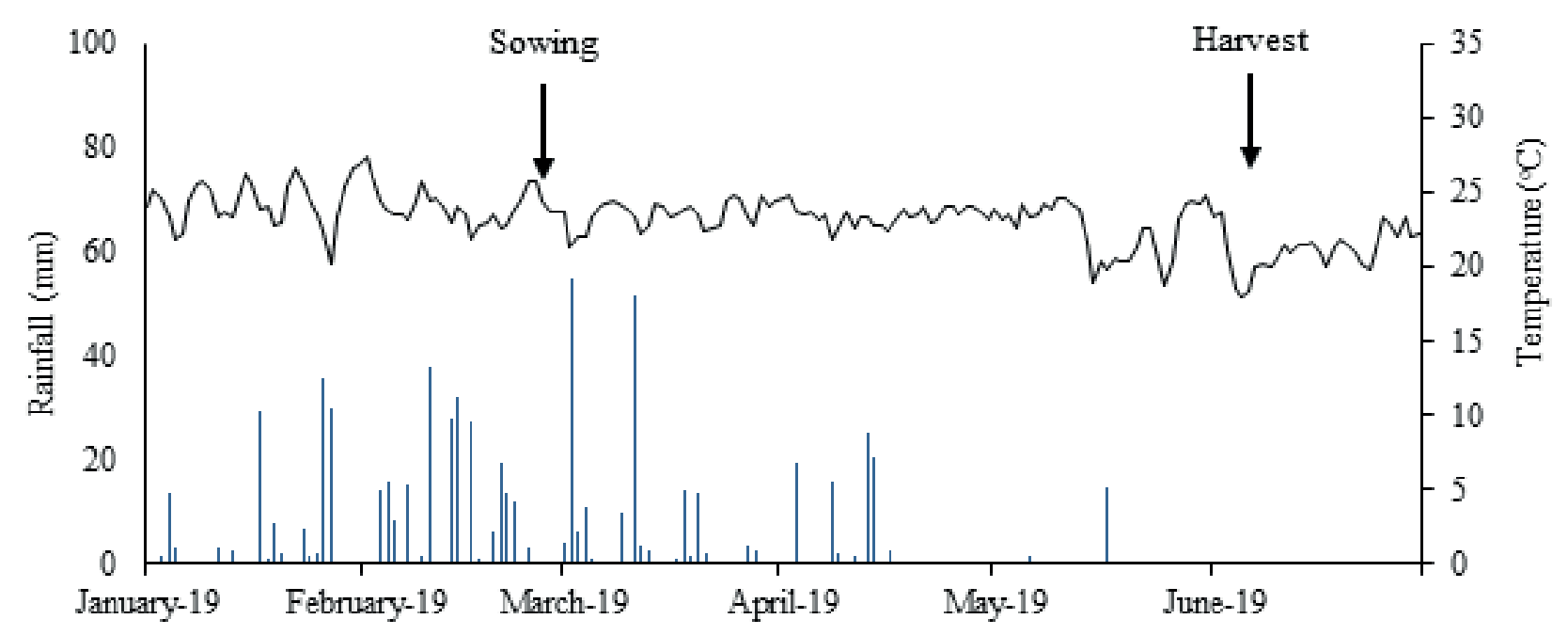

Source: INMET - Brazil's National Institute of Meteorology Collection station: Rio Verde (Goiás).

Figure 1. Rainfall $(\mathrm{mm})$ and average temperature $\left({ }^{\circ} \mathrm{C}\right)$ data during the period of the experiment. Rio Verde (Goiás), 2019.

and foliar diseases (Embrapa, 2021). The seeds were industrially treated with commercial products based on fludioxonil (fungicide) and thiamethoxam (insecticide). The sowing fertilization was carried out in the furrow applying the equivalent of $100 \mathrm{~kg} \mathrm{ha}^{-1}$ of monoammonium phosphate (MAP). Moreover, at 25 and 35 days after sowing, topdressing fertilization was performed, using urea and potassium chloride as sources, applying 120 and $100 \mathrm{~kg} \mathrm{ha}^{-1}$ of each fertilizer, respectively, with the doses divided by half in each fertilization.

To control voluntary soybean, an application of atrazine (1500 $\left.\mathrm{g} \mathrm{ha}^{-1}\right)$ was performed on the twentieth day after sowing sorghum. Excluding sourgrass plants, all other species present in the experimental units were weeded until the end of the experiment, so that there was no interference from other weeds on the treatments evaluated in sorghum. The management of pests and diseases was performed in accordance with the technical recommendations for sorghum, without letting them affect the crop's yield. All maintenance applications were carried out with a drag sprayer, adopting an application rate of $150 \mathrm{~L} \mathrm{ha}^{-1}$.

To evaluate the effect of increasing densities of sourgrass in coexistence with sorghum, the following response variables were evaluated: stand (plants per $\mathrm{m}$ ), plant height $(\mathrm{cm})$, stalk diameter $(\mathrm{mm})$, panicle length $(\mathrm{cm})$ and mass of 100 grains $(\mathrm{g})$, and yield $\left(\mathrm{kg} \mathrm{ha}^{-1}\right)$. The stand was evaluated considering 3 linear meters of the useful area of the plot and then calculated the average per linear meter. For plant height assessments, measurement of the distance 
between the soil surface (plant neck) and the beginning of the sheath of the last expanded leaf was performed with the aid of a graduated ruler; five plants were sampled per experimental unit. The stalk diameter was measured using a digital caliper, calibrating at the base of the sorghum stalk; five plants were sampled per experimental unit. Plant height and stalk diameter assessments were performed at harvest time.

In addition to the aforementioned assessments, panicle length, mass of 100 grains, and yield were also evaluated at harvest. The panicle length was obtained by randomly collecting panicles in five sorghum plants per experimental unit, which had the length measured from the base of the rachis to the apex of the panicle. The mass of 100 grains was obtained by counting 100 grains from plants present in the useful area of each experimental unit, and later these were weighed on a precision scale and had their moisture corrected to $13 \%$. To measure grain yield, panicles of sorghum plants present in the useful area were manually harvested and later threshed. Grain moisture was corrected to $13 \%$. The yield value obtained per experimental unit was converted to hectares, presenting yield results in $\mathrm{kg} \mathrm{ha}^{-1}$.

The statistical analysis of the data from the experiment was performed with the SISVAR computer program (Ferreira, 2011). All data were tabulated and subjected to analysis of variance by the $\mathrm{F}$ test and when a significant effect was observed, the data were subjected to regression analysis $(p \leq 0.05)$.

\section{Results and Discussion}

There are several factors that positively affect the development of the crop and help to obtain high yields. Among these, the crop stand stands out, which is mainly a result of the quality of sowing, in addition to the phytosanitary management practices (Pereira Filho \& Rodrigues, 2015). In this sense, there was a significant effect between the increase in sourgrass density and the final stand of sorghum plants: the increase in weed density in coexistence with the crop resulted in sorghum plant mortality (Figure 2A).

A reduction of one sorghum plant per linear meter was observed when the crop was subjected to coexistence with a density of approximately 1.47 sourgrass plants per $\mathrm{m}^{2}$. The negative effect of the sourgrass interference process in reducing the crop stand would hardly be reversed, even if management practices were adopted in the crop for this purpose. Sorghum has certain productive plasticity in the sense of compensating for failures in the crop stand without affecting yield; however, it has been shown in the literature that this behavior is valid for situations where there is a slight decrease in the recommended population $(180,000$ plants $\mathrm{ha}^{-1}$ ) (Carmo et al., 2020), a situation that is not consistent with the one observed in the experiment, since the decrease in the stand caused by the coexistence with the sourgrass plants was accentuated.

The vegetative parameters, plant height, 

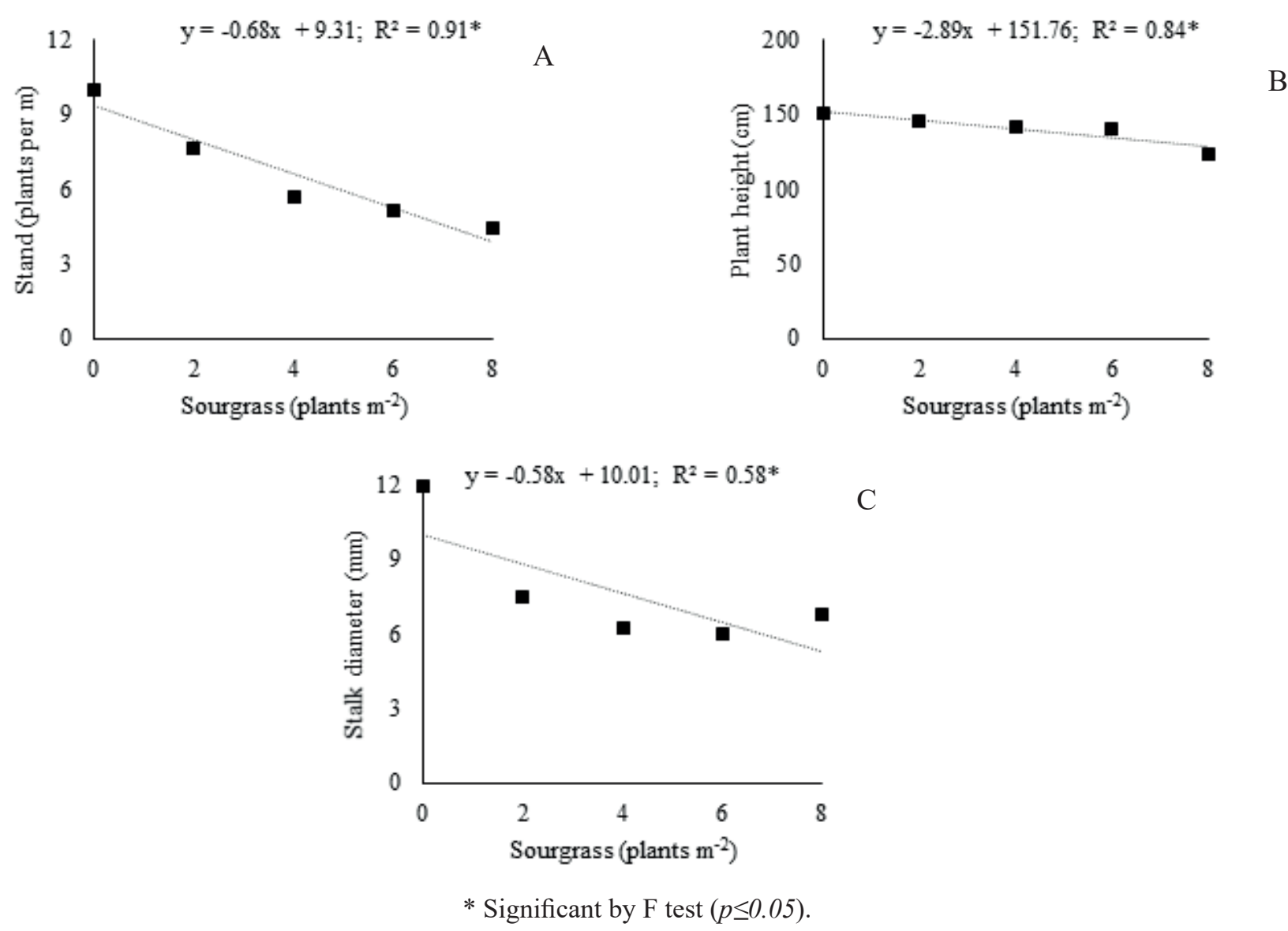

Figure 2. Stand, plant height, and stalk diameter of sorghum subjected to coexistence with increasing densities of sourgrass. Rio Verde (Goiás), 2019.

and stalk diameter are of high importance in the sorghum crop, as they provide an indication of how the plant's sustaining conditions are. Exacerbated increases in plant height, combined with reductions in stalk diameter, may bring as losses the increased susceptibility of the crop to lodging and/or toppling over, in addition to imposing restrictions on mechanized harvesting practices (Carmo et al., 2020, Rocha et al., 2020), demonstrating that these vegetative parameters are capable of impacting the final yield of sorghum. In this sense, Figures $2 \mathrm{~B}$ and
$2 \mathrm{C}$ present the results regarding the evaluation of plant height and stalk diameter as a function of the increase in sourgrass density in coexistence with the crop.

Regarding plant height, it is observed that the increase in the weed population density provided a linear reduction on this variable measured in the sorghum crop. For each sourgrass plant, there was a reduction of 2.89 $\mathrm{cm}(2 \%)$ in sorghum height values. For stalk diameter, the interference of sourgrass caused a reduction of approximately $47 \%$ of the value 
of this vegetative parameter of sorghum plants, considering the maximum density of sourgrass infestation evaluated ( 8 plants $\mathrm{m}^{-2}$ ). In a similar work, Silva et al. (2014a) reported that the lack of control of the weed community during the crop cycle causes a reduction in stalk diameter, which makes the crop plants more sensitive to lodging and breakage.

From the losses verified in the stand, plant height, and stalk diameter of sorghum, it is evident that the establishment of the crop was extremely affected by the coexistence with sourgrass, regardless of the density of individuals of this weed. In this context, taking into account only the results obtained for the vegetative parameters evaluated, it is already evident that there is no tolerance level regarding the coexistence of sourgrass and sorghum, suggesting that any and all plants of this species should be controlled in order to avoid crop development damage.

Consistent with the behavior observed for the vegetative parameters that were measured, the increase in sourgrass population negatively affected the yield components of sorghum (Figures 3A and 3B). The density increases in sourgrass plants caused a decrease in the length of the sorghum panicles, which consequently led to lower grain production. When the sorghum plants developed free from coexistence with sourgrass, the average panicle length observed was 23.12 $\mathrm{cm}$. In contrast, the maximum reduction in the values of this variable was verified in the highest weed population density ( 8 plants $\left.\mathrm{m}^{-2}\right)$, in which the decrease in the size of sorghum panicles was approximately $30.62 \%$.

By analyzing the statistical model adjusted for panicle length, a reduction of $1 \mathrm{~cm}$ in the size of these structures is verified when sorghum developed in coexistence with a density of 1.13 sourgrass plants per $\mathrm{m}^{2}$. Possibly, due to the competition process, the sourgrass plants reduced the availability of resources necessary for the development of sorghum reproductive structures (Cabral et al., 2013), a fact that culminated in the panicle size decrease.

The mass of 100 grains showed a reduction in the estimates according to the density increase of sourgrass plants (Figure 3B). This behavior can directly interfere with the final crop yield since the mass of 100 grains is one of the most important components of sorghum yield (Silva et al., 2015). Furthermore, changes in this variable become important from the point of view of technical recommendation, as it directly affects the crop's grain yield (Crusciol et al., 2011). To get an idea of the effect of the coexistence of sourgrass with sorghum on the mass of 100 grains, there was an average reduction in the values of this variable of approximately $2.3 \%$ in relation to the interference free (control without coexistence) for each plant of sourgrass $\mathrm{m}^{-2}$.

All crop yield components were negatively impacted by the coexistence with sourgrass, which indicates the final effect to be expected by the interference process of this weed on the final sorghum yield (Figure 3C). When exposed to conditions without sourgrass interference, the sorghum crop had a yield of $4068.40 \mathrm{~kg} \mathrm{ha}^{-1}$. For 


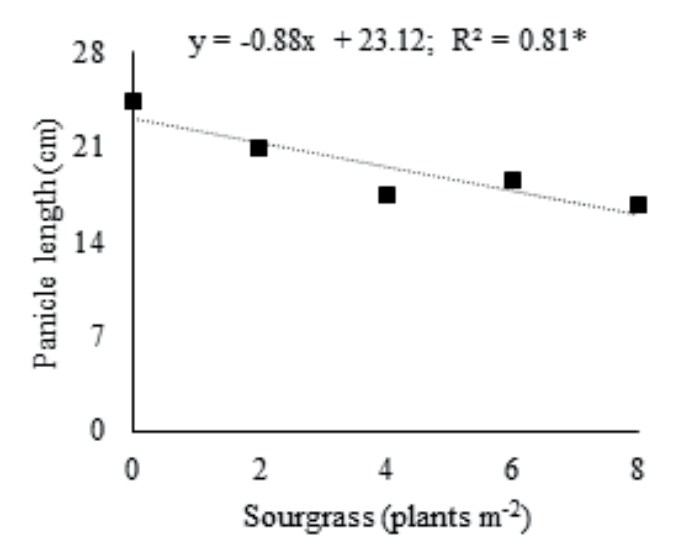

A

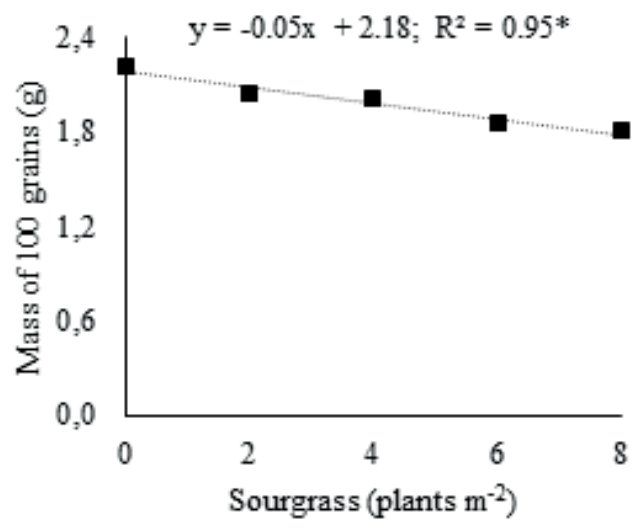

B

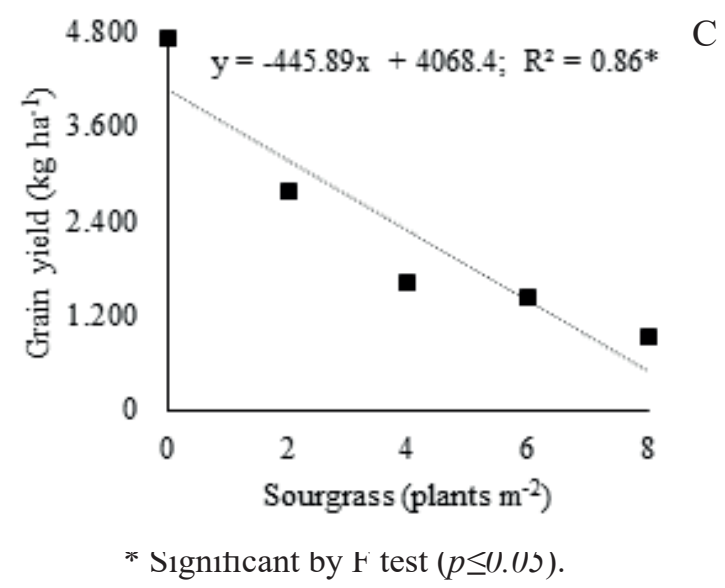

Figure 3. Panicle length, mass of 100 grains, and grain yield of sorghum subjected to coexistence with increasing densities of sourgrass. Rio Verde (Goiás), 2019.

each sourgrass plant added per square meter in coexistence with the crop, losses in the order of $445.89 \mathrm{~kg} \mathrm{ha}^{-1}\left(\approx 7\right.$ bags ha $\left.^{-1}\right)$ were observed. In percentage terms, the losses observed were estimated at $10.95 \%$ for each sourgrass plant increased by $\mathrm{m}^{2}$.

The reduction in sorghum yield was the result of a series of global effects that make up the process of interference of the weed on the crop, highlighting the competition for water, since the period in which the experiment was conducted was during lower water availability, in addition to competition for light, since the sourgrass quickly sprouted after the mowing operation carried out before sowing sorghum, imposing a shading condition on the sorghum crop plants. In this sense, the results of the present experiment clearly demonstrate the high potential for damage to the sorghum crop when it is subjected to coexistence with sourgrass. 
The whole scenario above is negatively potentialized when taking into account the higher initial development rate that the sourgrass presents at the expense of sorghum (Figure 4). In addition to this fact, there is a shortage of herbicides registered for grass control in this crop (Gemelli et al., 2012; Braz et al., 2019). In this sense, the need to adopt measures for the integrated weed management in the sorghum crop becomes evident. One of the alternatives for the management of the weed community refers to the adoption of practices related to cultural control, in which the use of cultivars with faster initial growth, reduction in row spacing, and increased plant density stand
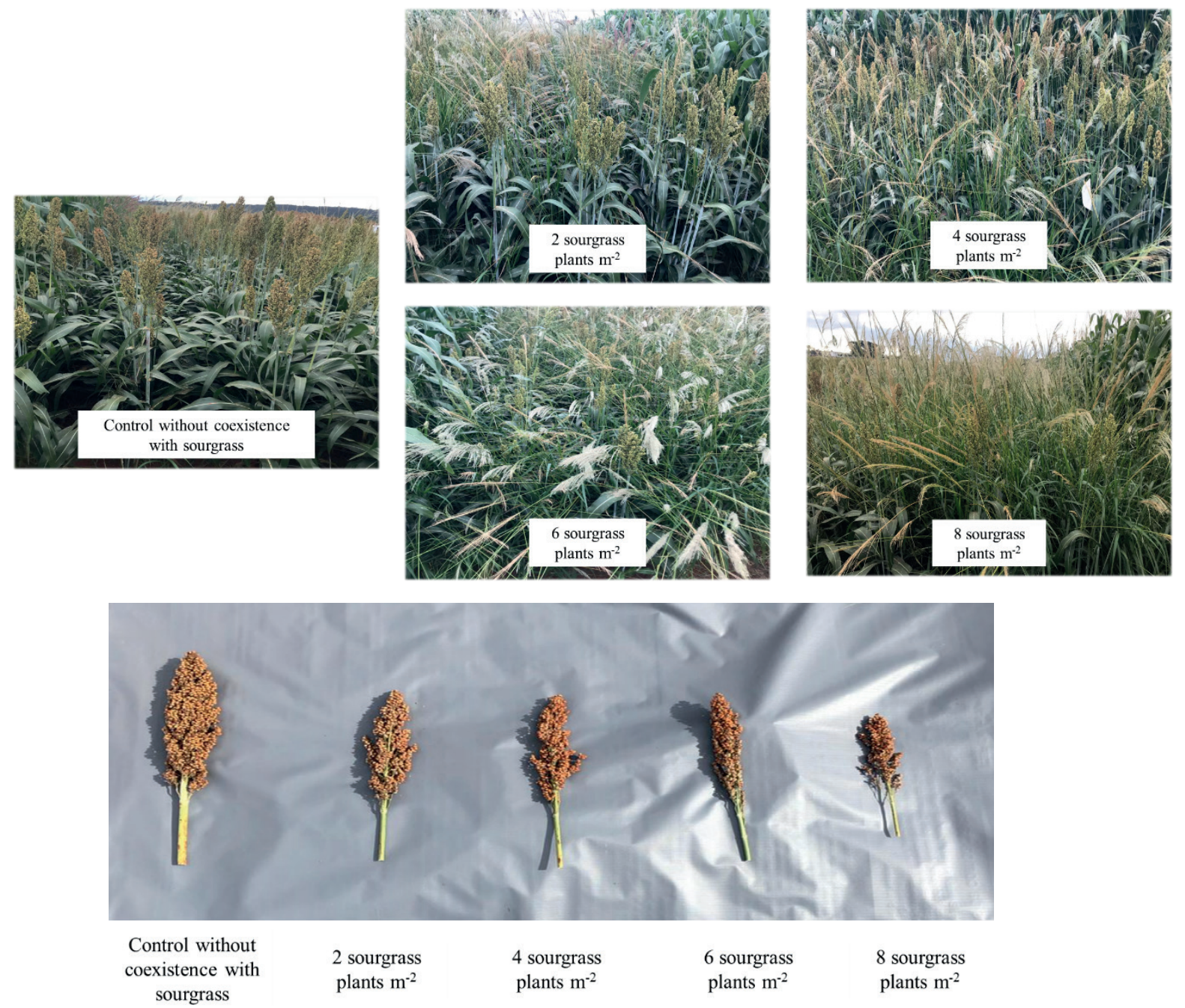

6 sourgrass
plants $\mathrm{m}^{-2}$

8 sourgrass plants $\mathrm{m}^{-2}$

Figure 4. Visual appearance of sorghum plants subjected to coexistence with increasing densities of sourgrass. Rio Verde (Goiás), 2019. 
out (Peerzada et al., 2016; Braz et al., 2019).

As for the chemical control of weeds in sorghum, as already discussed in this work, there is no extensive portfolio of herbicides registered for the crop, which makes it difficult to adopt this method in the management of the weed community. A study carried out by Silva et al. (2014b) pointed to efficacy in weed control and selectivity of S-metolachlor applied in pre-emergence of the crop, as long as its use is associated with the treatment of seeds with fluxofenim (safener). In this scenario, S-metolachlor becomes a good alternative to control sourgrass plants from seeds (Coradin et al., 2019). Despite this, this strategy is not effective in controlling sourgrass in plants from regrowth, as in the case of the present work.

Another possibility refers to reports in the literature on the potential use of the herbicide tembotrione. Despite not having a record for use in grain sorghum, it has already shown moderate selectivity potential for the crop, with differences in terms of sensitivity between hybrids, doses, and stages of application (Dan et al., 2009). However, it should be noted again that this herbicide has no record, and, therefore, studies would need to be carried out to assess the selectivity of tembotrione to sorghum in applications carried out post-emergence of the crop.

Summarizing the results generated in the present work, it is verified that sourgrass has a high potential of interference on the crop since all the growth and development parameters of sorghum were affected due to the presence and density increase of this weed. Specifically, in relation to yield, it appears that the interference imposed by the higher density of sourgrass plants provided an $87 \%$ reduction in the sorghum grain yield.

\section{Conclusions}

The increase in the density of sourgrass plants with sorghum negatively affects all characteristics evaluated in the crop.

There was a yield reduction of $445 \mathrm{~kg} \mathrm{ha}^{-1}$ for each sourgrass plant $\mathrm{m}^{-2}$ in coexistence with sorghum.

Reductions of $87 \%$ in sorghum grain yield were observed in relation to the control when the crop was subjected to coexistence with 8 sourgrass plants $\mathrm{m}^{-2}$.

\section{Acknowledgments}

Thanks to the Conselho Nacional de Desenvolvimento Científico e Tecnológico (CNPq) for the financial support for part of this work through the resources made available in the Chamada Universal $n^{\circ} 28 / 2018$.

\section{References}

ACOMPANHAMENTO da Safra Brasileira [de] Grãos: safra 2020/21: $11^{\circ}$ levantamento: v. 11, n. 11, agoosto 2021. Brasília, DF: Conab, 2021. 33 p. Available at: https://www.conab.gov.br/infoagro/safras/graos/boletim-da-safra-de-graos. Accessed on: 3 jan. 2021.

BRAZ， G. B. P.; CRUVINEL， A. G.; CANEPPELE, A. B.; TAKANO, H. K.; SILVA, A. G.; OLIVEIRA JR., R. S. Sourgrass 
interference on soybean grown in Brazilian Cerrado. Revista Caatinga, v. 34, n. 2, p. 350358, 2021. DOI: http://dx.doi.org/10.1590/198321252021v34n211rc.

BRAZ, G. B. P.; MACHADO, F. G.; CARMO, E. L.; ROCHA,A. G.C.; SIMON, G.A.;FERREIRA, C. J. B. Desempenho agronômico e supressão de plantas daninhas no sorgo em semeadura adensada. Revista de Ciências Agroveterinárias, v. 18, n. 2, p. 170-177, 2019. DOI: http://dx.doi. org/10.5965/223811711812019170.

BRAZ, G. B. P.; OLIVEIRA JR., R. S.; CONSTANTIN, J.; RAIMONDI, R. T.; RIBEIRO, L. M.; GEMELLI, A.; TAKANO, H. K. Plantas daninhas como hospedeiras alternativas para Pratylenchus brachyurus. Summa Phytopathologica, v. 42, n. 3, p. 233238, 2016. DOI: http://dx.doi.org/10.1590/0100$5405 / 2129$.

CABRAL, P. H. R.; JAKELAITIS, A.; CARDOSO, I. S.; ARAÚJO, V. T.; PEDRINI, E. C. F. Interferência de plantas daninhas na cultura do sorgo cultivado em safrinha. Pesquisa Agropecuária Tropical, v. 43, n. 3, p. 308-314, 2013. DOI: http://dx.doi.org/10.1590/S198340632013000300008.

CARMO, E. L.; SOUSA, J. V. A.; FERREIRA, C. J. B.; BRAZ, G. B. P.; SIMON, G. A. Agronomic performance of grain sorghum cultivated in double rows space on Brazilian Cerrado. Revista Caatinga, v. 33, n. 2, p. 422432, 2020. DOI: http://dx.doi.org/10.1590/198321252020v33n215rc.

CORADIN, J.; BRAZ, G. B. P.; MACHADO, F. G.; SILVA, A. G.; SOUSA, J. V. A. Herbicidas aplicados em pré-emergência para o controle de milho voluntário e capim-amargoso. Revista
Científica Rural, v. 21, n. 3, p. 28-38, 2019. DOI: https://doi.org/10.30945/rcr-v21i3.2785.

CLIMATE-DATA. Rio Verde Weather (Brazil). Available at: https://pt.climate-data.org/americado-sul/brasil/goias/rio-verde-4473/. Accessed on: 25 fev. 2021.

CRUSCIOL, C. A. C.; MATEUS, G. P.; PARIZ, C. M.; BORGHI, É.; COSTA, C.; SILVEIRA, J. P. F. Nutrição e produtividade de híbridos de sorgo granífero de ciclos contrastantes consorciados com capim-marandu. Pesquisa Agropecuária Brasileira, v. 46, n. 10, p. 12341240, 2011. DOI: http://dx.doi.org/10.1590/ S0100-204X2011001000017.

DAN, H. A.; BARROSO, A. L. L.; DAN, L. G. M.; PROCÓPIO, S. O; FERREIRA FILHO, W. C.; MENEZES, C. C. E. Tolerância do sorgo granífero ao herbicida tembotrione. Planta Daninha, v. 28, n. 3, p. 615-620, 2009. DOI: http://dx.doi. org/10.1590/S0100-83582010000300019.

EMBRAPA. Sorgo - BRS 310. Soluções tecnológicas. Available at: https://www.embrapa. br/busca-de-solucoes-tecnologicas/-/produtoservico/402/sorgo---brs-310. Accessed on: 23 fev. 2021.

FERREIRA, D. F. Sisvar: a computer statistical analysis system. Ciência e Agrotecnologia, v. 35, n. 6, p. 1039-1042, 2011. DOI: http://dx.doi. org/10.1590/S1413-70542011000600001.

GEMELLI, A.; OLIVEIRA JR., R. S.; CONSTANTIN, J.; BRAZ, G. B. P.; JUMES, T. M.C.; GHENO, E.A.; RIOS, F. A.; FRANCHINI, L. H. M. Aspectos da biologia de Digitaria insularis resistente ao glyphosate e implicações para o seu controle. Revista Brasileira de Herbicidas, v. 11, n. 2, p. 231-240, 2012. DOI: 
http://dx.doi.org/10.7824/rbh.v11i2.186.

HEAP, I. International herbicide-resistant weed database. Available at: http://www.weedscience. org/Pages/GeoChart.aspx. Accessed on: $23 \mathrm{fev}$. 2021.

MACHADO, V. D.; TUFFI SANTOS, L. D.; SANTOS JR., A.; MOTA, V. A.; PADILHA, S. V.; SANTOS, M. V. Fitossociologia de plantas daninhas em sistemas de integração de sorgo com braquiária sob diferentes formas de implantação da pastagem. Planta Daninha, v. 29, n. 1, p. 8595, 2011. DOI: http://dx.doi.org/10.1590/S010083582011000100011.

OVEJERO, R. F. L.; TAKANO, H. K.; NICOLAI, M.; FERREIRA, A.; MELO, M. S. C.; CAVENAGHI, A. L.; CHRISTOFFOLETI, P. J.; OLIVEIRA JR., R. S. Frequency and dispersal of glyphosate-resistant sourgrass (Digitaria insularis) populations across Brazilian agricultural production areas. Weed Science, v. 65, n. 2, p. 285-294, 2017. DOI: http://dx.doi.org/10.1017/ wsc. 2016.31 .

PEERZADA, A. M.; ALI, H. H.; CHAUHAN, B. S. Weed management in sorghum [Sorghum bicolor (L.) Moench] using crop competition: a review. Crop Protection, v. 95, p. 74-80, 2016. Special number. DOI: http://dx.doi.org/10.1016/j. cropro.2016.04.019.

PEREIRA FILHO, I. A.; RODRIGUES, J. A. S. Sorgo: o produtor pergunta, a Embrapa responde. Brasília, DF: Embrapa, 2015. 327 p. (Coleção 500 perguntas, 500 respostas).

PIMENTEL, G. V.; GUIMARÃES, D. F.; MOREIRA, S. G.; ÁVILA, M. O. T.; MARTINS, I. A.; BRUZI, A. T. Selectivity and effectiveness of herbicides in the grain sorghum crop. Planta Daninha, v. 37, e019187771, 2019.DOI:http://dx.doi.org/10.1590/s010083582019370100069 .

RIZZARDI, M. A.; KARAM, D.; CRUZ, M. B. Manejo e controle de plantas daninhas em milho e sorgo. In: VARGAS, L.; ROMAN, E. S. (ed.). Manual de manejo e controle de plantas daninhas. Bento Gonçalves: Embrapa Uva e Vinho, 2004. p. 571-594.

ROCHA, A. G. C.; CARMO, E. L.; BRAZ, G. B. P.; RIBEIRO JÚNIOR, L. F.; MENEZES, C. C. E.; SIMON, G. A.; SOUSA, J. V. A.; ROCHA, M. E. C. Agronomic performance of grain sorghum in different spatial arrangements. Semina. Ciências Agrárias, v. 41, n. 4, p. 1107-1118, 2020. DOI: http://dx.doi. org/10.5433/1679-0359.2020v41n4p1107.

RODRIGUES, A. C P.; COSTA, N. V.; CARDOSO, L.A.; CAMPOS, C. F.; MARTINS, D. Períodos de interferência de plantas daninhas na cultura do sorgo. Planta Daninha, v. 28, n. 1, p. 23-31, 2010. DOI: http://dx.doi.org/10.1590/ S0100-83582010000100003.

SANTOS, H. G. dos; JACOMINE, P. K. T.; ANJOS, L. H. C. dos; OLIVEIRA, V. A. de; OLIVEIRA, J. B. de; COELHO, M. R.; LUMBRERAS, J. F.; CUNHA, T. J. F. (ed.). Sistema brasileiro de classificação de solos. 2. ed. Rio de Janeiro: Embrapa Solos, 2006. $306 \mathrm{p}$.

SILVA, A. G.; HORVATH NETO, A.; TEIXEIRA, I. R.; COSTA, K. A. P.; BRACCINI, A. L. Seleção de cultivares de sorgo e braquiária em consórcio para produção de grãos e palhada. Semina: Ciências Agrárias, v. 36, n. 5, p. 2951-2964, 2015. DOI: http://dx.doi. org/10.5433/1679-0359.2015v36n5p2951. 
herbicide. Bioscience Journal, v. 30, n. esp., p. SILVA, C.; SILVA, A. F.; VALE, W. G.; GALON, 158-167, 2014b.

L.; PETTER, F. A.; MAY, A.; KARAM, D. Interferência de plantas daninhas na cultura do sorgo sacarino. Bragantia, v. 73, n. 4, p. 438-445, 2014a. DOI: http://dx.doi.org/10.1590/16784499.0119 .

SILVA, J. R. V.; MARTINS, C. C.; SILVA JÚNIOR, A. C.; MARTINS, D. Fluxofenim used as a safener on sorghum seed for S-metolachlor 